\title{
Animation Video of Eight National Heroes from North Sumatra: Digital Learning Media to Enhance Student Nationality Character
}

\author{
Deny Setiawan, ${ }^{1}$ Apriani Harahap, ${ }^{2}$ Rosnah Siregar, ${ }^{3}$ \\ \{denysetiawan1978@gmail.com ${ }^{1}$, aprianaiharahap@unimed.ac.id ${ }^{2}$, rosnahsiregar2015@gmail.com ${ }^{3}$ \} \\ ${ }^{1,3}$ Department of Citizenship Education Faculty of Social Science, Universitas Negeri Medan, \\ Indonesia \\ ${ }^{2}$ Department of History Education, Faculty of Social Science, Universitas Negeri Medan, Indonesia
}

\begin{abstract}
There are eight national heroes from Sumatra namely Sisingamangaraja XII, Ferdinand Lumban Tobing, Zainul Arifin, Tengku Amir Hamzah, Adam Malik, Kiras Bangun, Teuku Mohammad Hasan, and Tahi Bonar Simatupang who have a strong national character to be encouraged and imitated by students of North Sumatra. However, the national character is only contained in a learning textbook that has not been utilized as a digital learning media. For this reason, the animated video of eight National Heroes from North Sumatra is a digital learning media that is appropriate for enhancing the national character of colleger. The research aims to develop an animated video learning media that displays eight national characters of eight national heroes from North Sumatra. This research uses research and development methods. The results showed that this animated video is very interesting to be used as a digital learning media to enhance the national character of students.
\end{abstract}

Keywords: Animation, National Hero, Learning Media, National Character.

\section{Introduction}

Menristekdikti Mohamad Nasir stressed that improving the quality of education requires equitable distribution of education through the use of information technology such as learning through digital learning which is currently developing [1]. Higher education is required to utilize digital technical technology as a medium and source of learning. Unfortunately, the implementation of tertiary institutions has not yet maximized this digital era as an innovative learning process. This means that there are obstacles in human resources that have not been able to use high technology as a digital learning media. It takes hard work, ways, and breakthroughs in overcoming these problems. Digital learning has many advantages if applied properly and appropriately in learning [2], [3].

One of the right digital media in the development of instructional media is video animation of characters such as cartoons or anime that are loved by young people at this time. Video animation of characters is also very appropriate to be a breakthrough in increasing the application of digital or e-learning in the implementation of courses and as a supplement to Blended learning models for millennial students" nowadays" or "generation $z$ " which they already use in their smartphones. For this reason, this animated video is very suitable to be applied in one of the material in one particular subject.

The problem in lectures, especially lecturers supporting most subjects, is experiencing obstacles in the development of digital media or learning resources. Media or sources that are 
often used by lecturers are print media (printed books, ppt, modules, handouts, etc.). Although there are lecturers who use a variety of media to the fullest [4]. Even though everyday students don't miss carrying or reading print media because of the convenience of using gadget media (HP Android) which has a lot of content and applications that can be read, watched, downloaded. Students do not need to bother carrying heavy media/printed books because most books have been digitalized. To get around these problems lecturers should be able to develop digital learning media.

The instructional video animation media is very appropriate when used as an alternative for lecturers in developing learning media for millennial students. Besides, based on preliminary observations and experience as a lecturer, the use of video character animation media as a learning medium is rarely developed and applied to students specifically in the Faculty of Social Sciences, Medan State University. Plural, lecturers only rely on print media or textbooks in the learning process so that most students feel bored, monotonous, and do not attract the attention of students especially writers who realize they are less able to make humor as a distraction.

This character animated video will develop local historical values that contain an increase in the national character 8 Heroes of North Sumatra. This local content will also counter the canon of history or the narrative of a large "national hero" that has been rooted in the collective memory of students from elementary school to elementary school to university. It can be seen that when we question who the national heroes are to students, I always answer Kartini, Diponegoro, Tuanku Imam Bonjol and or other national figures. Very rarely do they know that North Sumatra has eight national heroes including Sisingamagaraja XII which are on a par with other national heroes. Even though the eight national heroes have local wisdom values in the form of morals, customs, characters and unique forms of struggle that can be a common thread in the development of the values of the civil servant and the national character of the North Sumatra local hero.

It is very appropriate if the float of nationalism values of eight national figures through character animation videos was developed in the learning process on campus. So that the generation of students knows, imitates and exemplifies the nationalism values of eight North Sumatra national figures to improve their national character. Besides, this video can also be material in analyzing, reasoning, and reconstructing events that happened to eight national heroes in North Sumatra.

\section{Research method}

This study uses a development model according to reference [5]. The development model is summarized into three stages of development activities carried out through: (1) The first stage of the preliminary study is the observation and literature study. (2) The second stage is the development stage which consists of compiling material, making storyboard scripts, making videos and editing video animations. (3) The third stage is an evaluation in the form of questionnaire results conducted on one expert lecturer and instructional media on the history of education, small groups and reviews from students. This evaluation stage is the final stage of the learning media development process. As described briefly in the following.

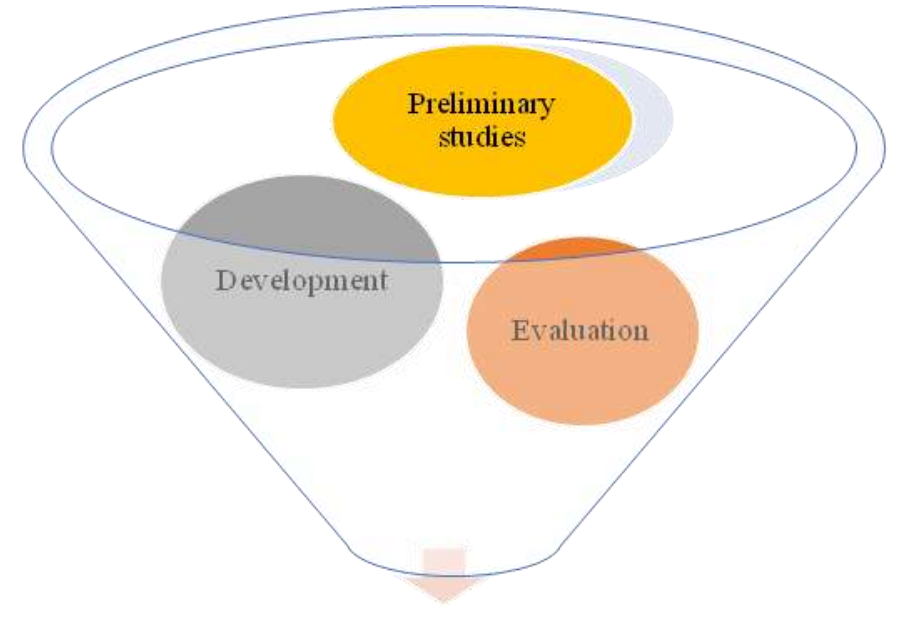




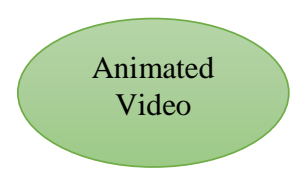

Fig. 1. Chart of research stages

The subject of this research is a lecturer who is an expert in design and learning media of historical education Dr. Phil. Ichwan Azhari, MS, one group for product testing and 30 people for field testing included first-semester Citizenship Education students at the Faculty of Social Sciences, Medan State University because researchers served as teaching staff who taught. Data collection methods used in this study were literature study and questionnaires. A literature study is used to find primary and secondary data to make material and manuscripts about the history and nationalism values of eight national heroes from North Sumatra. The questionnaire method is used for data collection to collect the results of product reviews from expert lecturers and media for learning history education, small groups and reviews from students by using Likert to measure attitudes, opinions, and perceptions. The results of the collected data are then analyzed using quantitative descriptive analysis techniques[6].

Table 1. Questionnaire rating scale

\begin{tabular}{cc}
\hline Answer & Score \\
\hline Very good & 5 \\
Well & 4 \\
Enough & 3 \\
Not good & 2 \\
Very Bad & 1 \\
\hline
\end{tabular}

(Source: Reference [6])

Data from the subject of the next review will be interpreted with qualitative sentences based on the average data obtained and the criteria for each data in the form of a percentage using the following formula.

$$
\text { Percentage }(\%)=\frac{\text { Total Score } \times 100 \%}{\text { Maximum Score }}
$$

The conclusion reached has been based on the percentage data assessment criteria as in the following Table 2 below.

Table 2. Data evaluation criteria for product validation

\begin{tabular}{ccc}
\hline no. & score $(\boldsymbol{\%})$ & conclusions and follow up \\
\hline 1 & $80-100$ & Valid / Not Revised \\
2 & $65-80$ & Valid enough / Revision (revalidation) \\
3 & $\leq 65$ & Invalid / Revised (revalidated) \\
\hline
\end{tabular}


If the results obtained reach a score of $80 \%$ and above, it can be concluded that the learning media developed in this study already meet valid criteria.

\section{Results and discussion}

The development of the animation media of eight National Heroes from North Sumatra has been carried out by producing three stages namely a preliminary study, development, and evaluation consisting of expert evaluation, small group evaluation and field test [8]. At the preliminary stage of the study an observation was made in several classes of subjects with the result that the lecturer had not yet maximized using digital media, the lecturer only used media powerpoint and only used the text buke to deliver teaching and learning activities to students in the Department of Citizenship Education at the Faculty of Social Sciences so that students just sit quietly, less focused, bored and focused only on the lighting of the lecturer in question. As a result, sixteen meetings were only in the form of listening, taking notes, group discussions and focusing on the lecturers. For this reason, innovative and creative learning media are needed to overcome these problems.

After getting the results of these observations, then the next stage is a literature study to produce material and manuscripts of eight national heroes from North Sumatra. The results of the literature study are material that contains the national values of the 8 Heroes of North Sumatra, which have been summarized in the form of a table as follows:

Table 3. National Values of the Eight Heroes of North Sumatra

\begin{tabular}{|c|c|c|}
\hline no. & $\begin{array}{l}\text { the name } \\
\text { of the hero }\end{array}$ & persona \\
\hline 1 & $\begin{array}{l}\text { Sisingaman } \\
\text { garaja XII }\end{array}$ & $\begin{array}{l}\text { Fighting the Dutch invaders and moving } \\
\text { their citizens in the Lake Toba, Bakkara, } \\
\text { Tapanuli, Sibolga, Bahal Batu, and Aceh } \\
\text { regions. The character value is Brave, } \\
\text { tough, never give up and fight until the } \\
\text { last blood. }\end{array}$ \\
\hline 2 & $\begin{array}{l}\text { Ferdinan } \\
\text { Lumbantob } \\
\text { ing }\end{array}$ & $\begin{array}{l}\text { Guerrilla fight against the invaders in } \\
\text { military aggression in Tapanuli. }\end{array}$ \\
\hline 3 & $\begin{array}{c}\text { Kiras } \\
\text { Bangun }\end{array}$ & $\begin{array}{l}\text { Raising interfaith forces in North Sumatra } \\
\text { and Aceh to oppose Dutch colonialism. }\end{array}$ \\
\hline 4 & $\begin{array}{l}\text { Kiai Haji } \\
\text { Zainul } \\
\text { Arifin }\end{array}$ & $\begin{array}{l}\text { As representatives of the Nahdalatul } \\
\text { Ulama (Masyumi) and commander of the } \\
\text { Hezbollah army (Allah's army) guerrilla } \\
\text { against the invaders until the transfer of } \\
\text { sovereignty in } 1949 .\end{array}$ \\
\hline 5 & $\begin{array}{l}\text { Tengku } \\
\text { Amir } \\
\text { Hamzah }\end{array}$ & $\begin{array}{l}\text { Literary and article columnist who } \\
\text { criticized the government through the } \\
\text { New Pujangga magazine media and was } \\
\text { active in the activities of the Free } \\
\text { Indonesian National Movement } \\
\text { organization. }\end{array}$ \\
\hline 6 & $\begin{array}{l}\text { Adam } \\
\text { Malik }\end{array}$ & $\begin{array}{l}\text { Guerrilla in the youth movement in } \\
\text { preparation for Indonesian independence } \\
\text { and the Japanese period. }\end{array}$ \\
\hline
\end{tabular}

national character value

Warrior, patriot, brave, tough, uphold self-esteem, mighty, never give up, fight until the last blood and willing to sacrifice

Brave, tough fighters, never give up, fight until the last blood and willing to sacrifice

The drafter, the percolator of the idea of nationalism, brave, tough, willing to sacrifice and never give up. Islamic leaders, movers, courageous, tough, willing to sacrifice and never give up.

The drafter, the percolator of the idea of nationalism, brave, tough, willing to sacrifice and never give up.

Warriors, patriots, brave, tough, never give up, and willing to sacrifice. 
Teuku

Mohamma

d Hasan

T. B.

Simatupang
Guerrilla fight against invaders from 1942-1945, became a member of the Indonesian Independence Preparatory Committee (PPKI), the Governor of Sumatra I, Vice-Chair of the PDRI and chair of the DPRS Trade / Industry Commission and nationalized the Petroleum Company. Join the TKR (People's Security Army) during the independence of the Republic of Indonesia and guerrilla with the Armed Forces Commander General Soedirman
Warriors, patriots, brave, tough, never give up, and willing to sacrifice.

Warriors, patriots, brave, tough, strong never give up, fight until the last blood and willing to sacrifice. against Dutch forces.

The character and national character values of the eight national heroes from North Sumatra above will be shown in this $2 \mathrm{D}$ animated video to students so that learning is more innovative, interesting, fun, and reduces boredom. The second stage is the development which consists of compiling material and storyboard manuscripts. The storyboard manuscript consists of four slides that contain births, figures or characters, national values and the end of the struggle of eight national heroes from North Sumatra. Then the second step is to make a 2D character animated video using Adobe After Effects tools and other supporting software. Here it is designed with a process that requires time, rather difficult work methods with the basic principles of making $2 \mathrm{D}$ animation [9]. After the video is finished, the editing process, the preview of repairs (revised program) and reproductive multiplication are carried out to test the validity level as an animated video. For example, the display of the animated video character 2D Sisingamagaraja XII.
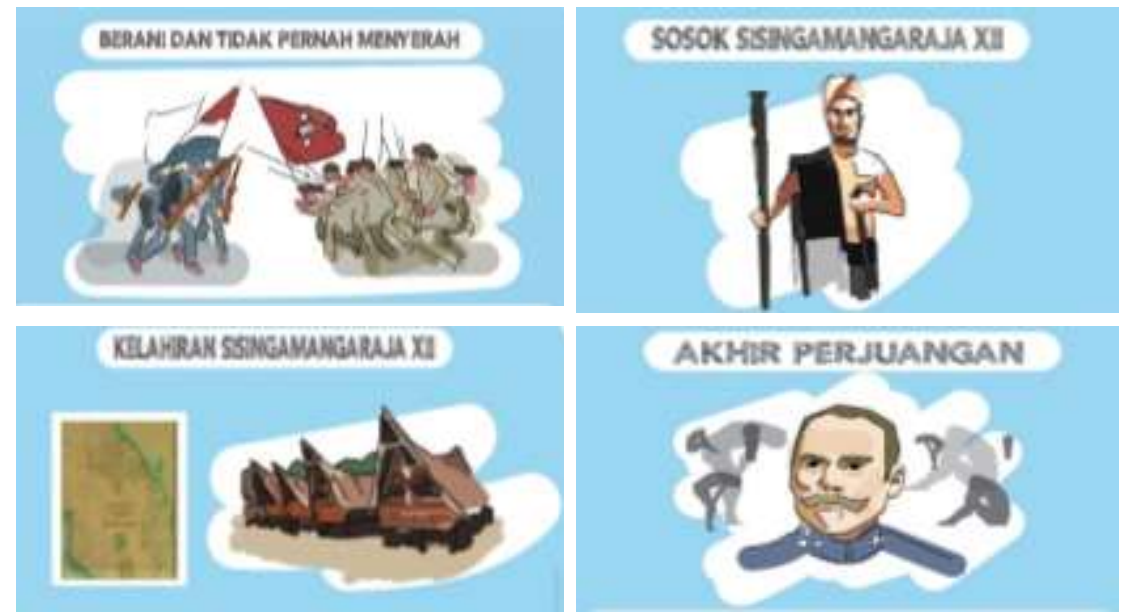

Fig. 2. Video animation character display 2 D Sisingamangaraja XII

The last stage is the evaluation stage. This stage consists of several steps, the first step is an evaluation of the learning media experts by providing a sample of this animated video. Then the animation is assessed by giving a checkmark to the column listed on the validation 
sheet provided. The validator gave a response about this animated video both its strengths and weaknesses to be used as a reference for further improvement. Based on the results of quantitative descriptive data analysis to the validator or instructional media experts produced a percentage of $84 \%$. The percentage shows the results under the percentage scale which is categorized as good/valid which means that the video animation of the character is good and is successful for students to watch and under the objectives of the theme and the objectives of the learning process. This is similar to the fact that the benefits of learning media such as animation can make it easier for students to achieve learning goals[10].

The next step is to evaluate the small group that is conducted for the first-semester Citizenship Education students of the Faculty of Social Sciences, Medan State University. This evaluation was conducted on 30 students with different abilities. This stage produces an assessment of $94.66 \%$ with a very good or very interesting category. This means that this animated video is very interesting as a medium of learning for students. This conclusion is in line with the opinion of Ngozi-Olehi that animation media can make students understand, add to the pleasant atmosphere and increase appreciation/interest in this course [11]. To see the increase in the national character of students conducted a test of learning outcomes knowledge. This step is done by sharing the animated video through WhatsApp to students with several question sheets about national character. The results obtained from this step are complete with a percentage of $85 \%$. Based on these results, it shows that students remember and do national character values in the surrounding environment.

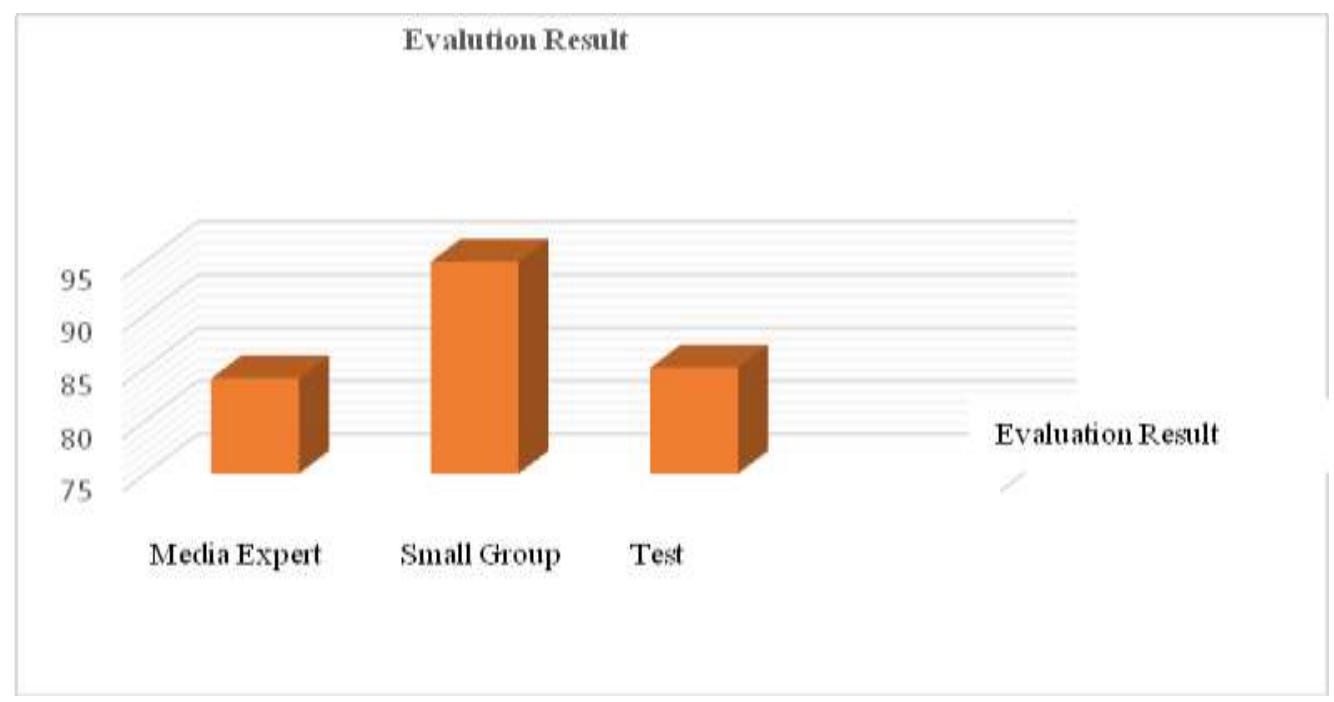

Fig. 3. Animation Video Evaluation Results (Researcher Data, October 2019)

Thus from the conclusion of the graphic animation media based on eight national heroes from North Sumatra has proven its validity, practicality, interesting, fun and not boring and affects increasing student interest in learning and increasing the value of national character. This animated video media is very appropriate to be used as an innovative learning media and 
can instill the national character of students who have eroded in this era and foster a spirit of patriotism and patriotism so that it is not disturbed by radicalism and brutalism.

\section{Conclusion}

Figures 94.66 percent of the final assessment of students prove that the use of video animation of eight national heroes from North Sumatra is very attractive as a digital learning media. Student interest in this animated video has an impact on increasing the national character of students towards their environment according to the final evaluation of research with $85 \%$ complete results. Floating this animated video is the right media, interesting, fun and innovative in the learning process for students, especially in North Sumatra.

\section{References}

[1] Ristekdikti, "Kreatif dan Inovatid di Era Revolusi 4.0," Ristekdikti, Jakarta, 2018.

[2] Azhar Arsyad, Media Pembelajaran. Jakarta: Raja Grafindo Persada, 2011.

[3] Nana Sudjana dan Ahmad Rivai, Teknologi Pengajaran. Bandung: Sinar Baru Algesindo, 2003.

[4] Muchlas Samani, "Pembelajaran Inovatif dan Partisipatif," Jakarta, 2007.

[5] W.R. Borg \& M.D. Gall, Educational Research: An Introduction, Fifth Edition. New York: Longman, 1983.

[6] Sugiyono, Metode Penelitian Kuantitatif Kualitatif dan R\&D. Bandung: Alfabeta, 2008.

[7] Nana Syaodih Sukmadinata, Metode Penelitian Pendidikan. Bandung: Rosdakarya, 2007.

[8] B. Warsita, Teknologi Pembelajaran: Landasan dan Aplikasinya. Jakarta: Rineka Cipta, 2008.

[9] Partono Soenyoto, Animasi 2 D. Jakarta: PT: Elex Media Kamputindo, 2017.

[10] Ega Rima Wati, Ragam Media Pembelajaran. Yogyakarta: Kata Pena, 2016.

[11] Ngozi-Olehi L.C, "Improving Interest and Performance in Organic Chemistry Pedagogy by Incooperating Animations," American Journal of Educational Research, vol. 6, no. 3, pp. 277-280, 2018. 